\title{
BIO-PLASTIC COMPOSITE SUBSTRATE MATERIAL BASED MICROSTRIP-FED PRINTED ANTENNA FOR WIRELESS COMMUNICATIONS
}

\author{
TISKANA ANTENA ZA BREZŽIČNO KOMUNIKACIJO IZ \\ BIOPLASTIČNEGA KOMPOZITA Z MIKROTRAKOM ZA \\ NAPAJANJE
}

\author{
Touhidul Alam ${ }^{2,3}$, Mohammad Rashed Iqbal Faruque ${ }^{1}$, Mohammed Shamsul Alam³, \\ Md. Moinul Islam ${ }^{1}$, Md. Zulfiker Mahmud², Mohammad Tariqul Islam² \\ ${ }^{1}$ Universiti Kebangsaan Malaysia, Space Science Center (ANGKASA), 43600UKM, Bangi, Selangor, Malaysia \\ 2Universiti Kebangsan Malaysia, Department of Electrical, Electronic and Systems Engineering, 43600UKM, Bangi, Selangor, Malaysia \\ ${ }^{3}$ International Islamic University Chittagong, Department of Computer Science and Engineering, Chittagong, Bangladesh \\ touhid13@siswa.ukm.edu.my, tariqul@ukm.edu.my
}

Prejem rokopisa - received: 2015-09-02; sprejem za objavo - accepted for publication: 2015-01-06

\begin{abstract}
This paper presents a printed bio-plastic wireless antenna to ensure biological compatibility between humans and wireless devices. The antenna has multiband characteristics, which can cover the GSM 1800, UMTS (1.92-2.17 GHz), LTE 40 frequency bands. The proposed antenna is incorporated with a circular slotted hexagonal radiator with a microstrip feed line and a rectangular slotted ground plane. The wireless mobile antenna has been designed and simulated using the commercially available electromagnetic (EM) simulation software CST Microwave Studio. The EM absorption rate of the proposed antenna has also been analysed with a human head phantom.

Keywords: antenna, bio-plastic material, electromagnetic absorption, wireless communication

Članek predstavlja brezžično anteno, tiskano iz bioplastike, za zagotavljanje biološke kompatibilnosti med človekom in brezžičnimi napravami. Antena dosega večpasovne karakteristike, ki lahko pokrijejo GSM 1800, UMTS (1.92-2.17 GHz) in LTE 40 frekvenčni pas. Predlagana antena je sestavljena iz šestoglatega sevalnika s krožno odprtino in z napajalnim trakom povezano štirioglato ozemljitveno ploščo. Brezžična antena je bila skonstruirana in simulirana s pomočjo komercialne elektromagnetne (EM) programske opreme za simulacijo CST Microwave Studio. EM absorpcijska hitrost predlagane antene je bila analizirana s pomočjo umetne človeške glave.

Ključne besede: antena, bioplastičen material, elektromagnetna absorpcija, brezžična komunikacija
\end{abstract}

\section{INTRODUCTION}

With the rapid development of science and technology, the mobile wireless industry has expanded very quickly over the last decades. Thereby, health concern regarding the use of mobile wireless devices near human body has been growing and given special consideration by researchers. Moreover, the development of an environment-friendly composite material technology has been promulgated around the world.

Several antennas have been developed for mobile wireless communication by conventional fossil petroleum-based material. ${ }^{1-3}$ The electromagnetic absorption reduction of the wireless handset antenna has been analysed in many studies. C. Picher et al. ${ }^{4}$ proposed a slotted ground PIFA antenna for specific absorption analysis. A. Cabedo et al. ${ }^{5}$ proposed a handset antenna combining PIFA, slot and ground plane and analysed EM absorption value. A multi-standard wireless application has been made in ${ }^{6}$.

The analysis of printed antenna on an organic multilayers substrate has been developed in recent years. The conventional fossil petroleum-based material is replaced by a bio-based composite substrate. M. H. Ullah and M. Islam $^{7}$ proposed bio-based material for patch antenna design. He achieved $55.6 \%$ of the impedance bandwidth at a lower frequency and $24 \%$ of impedance bandwidth at the upper frequency band. However, the electromagnetic absorption analysis did not perform. A dual arm structured wireless antenna has been developed for mobile wireless applications, which covers the DCS, PCS, UMTS and WLAN $(2.4 \mathrm{GHz})$ frequency bands with an antenna size of $119 \times 50 \mathrm{~mm}^{2}{ }^{8}$ Q. Rao and T. A. Denidni $^{9}$ proposed an inverted $\mathrm{L}$ shaped antenna for DCS, PCS, and IMT tri-bands applications. S.-B. Chen et al. ${ }^{10}$ developed planar antennas for DCS 1800, PCS 1900, UMTS and WLAN applications. Here, the antenna dimensions are $65 \mathrm{~mm}^{2} \times 40 \mathrm{~mm}^{2}$.

In this paper, an organic or bio plastic-based substrate antenna is proposed for mobile wireless communications and the electromagnetic absorption behaviour has been explored. Moreover, the proposed antenna paraded multiband, which covers GSM 1800, UMTS 2100, WLAN 2400, WiMAX 2500, WiMAX 3600 and WLAN 5GHz. 
T. ALAM et al.: BIO-PLASTIC COMPOSITE SUBSTRATE MATERIAL BASED MICROSTRIP-FED PRINTED ANTENNA ...

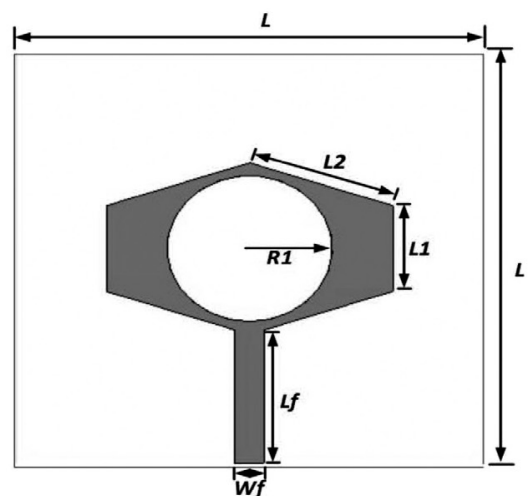

(a)

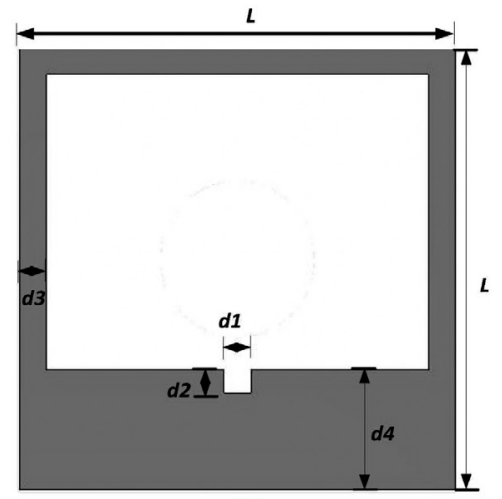

(b)

Figure1: Geometry of the proposed antenna: a) top view, b) bottom view

Slika 1: Geometrija predlagane antene: a) pogled od zgoraj, b) pogled od spodaj

\section{PROPOSED ANTENNA CONFIGURATION}

The geometric layout of the proposed antenna is illustrated in Figure 1. It is seen from Figure 1 that the antenna consists of a circular slotted hexagonal patch, which is connected with a $50 \Omega$ microstrip feed line. A rectangular slot was etched from the ground plane. The antenna design parameters are tabulated in Table 1. The proposed antenna is designed on a bio-plastic material (relative permittivity 12) substrate with dimensions of $48 \times 48 \times 1.95 \mathrm{~mm}^{3}$.

Table 1: Antenna parameters

Tabela 1: Parametri antene

\begin{tabular}{|c|c|c|c|}
\hline Parameter & Value $(\mathrm{mm})$ & Parameter & Value $(\mathrm{mm})$ \\
\hline$L$ & 48 & $R$ & 8.5 \\
\hline$L 1$ & 10 & $d 1$ & 3 \\
\hline$L 2$ & 15.55 & $d 2$ & 2.5 \\
\hline$L f$ & 15.5 & $d 3$ & 5.83 \\
\hline$W f$ & 3.10 & $d 4$ & 13.08 \\
\hline
\end{tabular}

\section{ANTENNA SUBSTRATE}

The processing steps flowchart of the bio-plastic substrate material is presented in Figure 2. Habib et al.

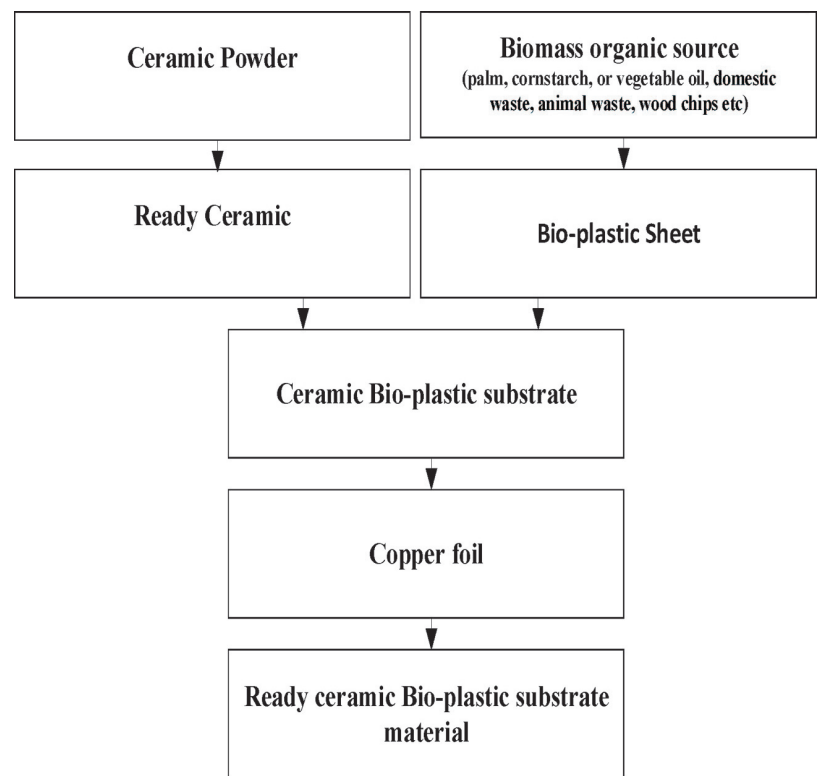

Figure 2: Flowchart of the manufacturing of bio-plastic substrate material

Slika 2: Potek izdelave podlage iz bio-plastike

proposed and analysed the antenna characteristics using bio-plastic substrate material. He also described the bio-plastics manufacturing procedures. The procedure begins with moulding ceramic powder and then mixing with polymeric binder preforming substances, such as cellulose. For sintering the ceramic powder the polymeric sponge method was used. Besides this, bio-plastic sheet is prepared from a biomass organic source, such as palm, corn starch, or vegetable oil. A three-layered sandwich structure of $59-\mathrm{ml}(1.5-\mathrm{mm})$ thick ceramic, both surfaces covered by a $0.25-\mathrm{mm}$ bio plastic, is pressed using a multi-press machine (RMP 210, Bungard Elektronik $\mathrm{GmbH} \& \mathrm{Co}$ ).

\section{RESULTS AND DISCUSSION}

The proposed antenna was fabricated using bio-plastic material. The fabricated prototype of the proposed antenna is illustrated in Figure 3. The antenna performances were measured using a fabricated prototype. The reflection coefficient of the proposed antenna was measured using an Agilent N5227A performance network analyser. The measured and simulated reflection coefficient is presented in Figure 4. It is observed from Figure 4 that the proposed antenna shows a measured -10dB impedance bandwidth of $620 \mathrm{MHz}$ (1.6-2.22 $\mathrm{GHz}), 830 \mathrm{HMz}(3.43-4.26 \mathrm{GHz})$ and $1.17 \mathrm{GHz}(4.8-$ $5.97 \mathrm{GHz}$ ). It is seen from Figure 4 that the measured resonance frequencies are nearly identical to the simulate one. Though there is a mismatch between the measured and simulated reflection coefficient, which is possibly attributed due to manufacturing tolerances and the imperfect soldering effect of the SMA connector. Moreover, surface current distribution at $1.8 \mathrm{GHz}$ and $5.2 \mathrm{GHz}$ 
T. ALAM et al.: BIO-PLASTIC COMPOSITE SUBSTRATE MATERIAL BASED MICROSTRIP-FED PRINTED ANTENNA ...

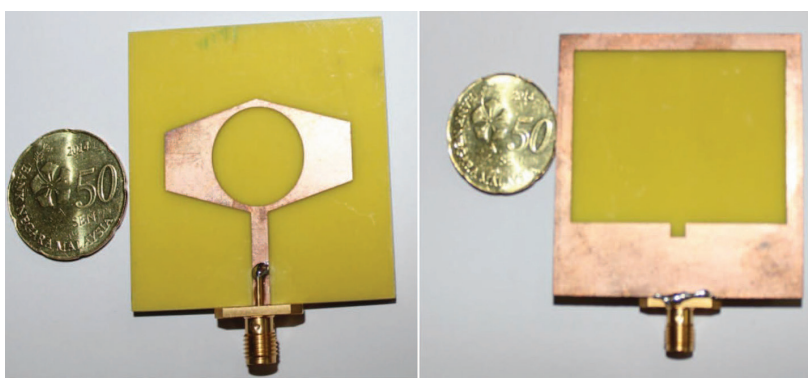

Figure 3: Fabricated antenna prototype

Slika 3: Izdelan prototip antene

is shown in Figure 5 for the radiating behaviour of the antenna.

The radiation pattern of the proposed antenna was measured using the satimo near-field measurement system. Figure $\mathbf{6}$ demonstrates the measured radiation pattern at $(1.8,2.0,3.6$, and 5.2) GHz. It is observed from Figure 6 that the antenna sshows a nearly omnidirectional radiation pattern, though cross polarization is high at higher frequency. Moreover, 3D radiation attern is also presented for more visualization of the radiation

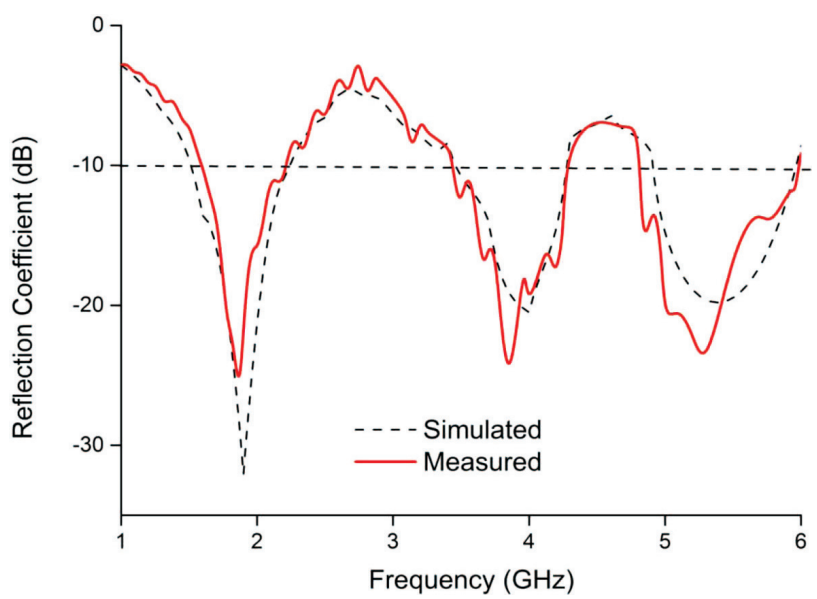

Figure 4: Simulated and measured reflection coefficient of the proposed antenna

Slika 4: Simuliran in izmerjen koeficient sevanja predlagane antene

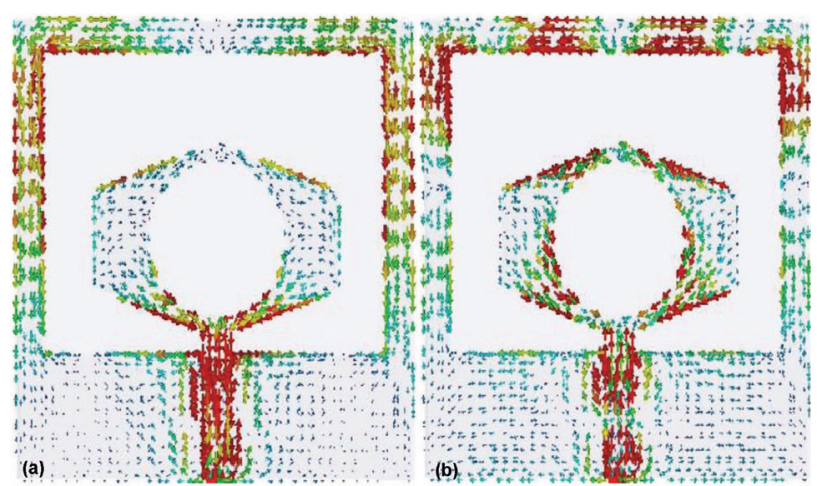

Figure 5: Surface current distribution of the proposed antenna: a) $1.8 \mathrm{GHz}$ and b) $5.2 \mathrm{GHz}$

Slika 5: Razporeditev toka na površini predlagane antene: $1,8 \mathrm{GHz}$ in b) $5,2 \mathrm{GHz}$

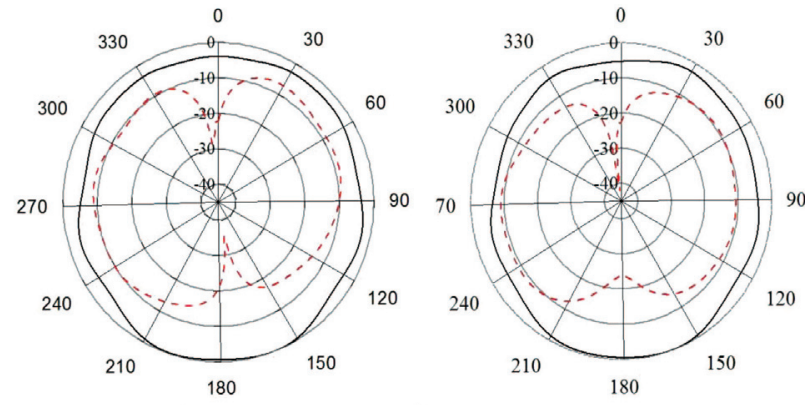

(a)

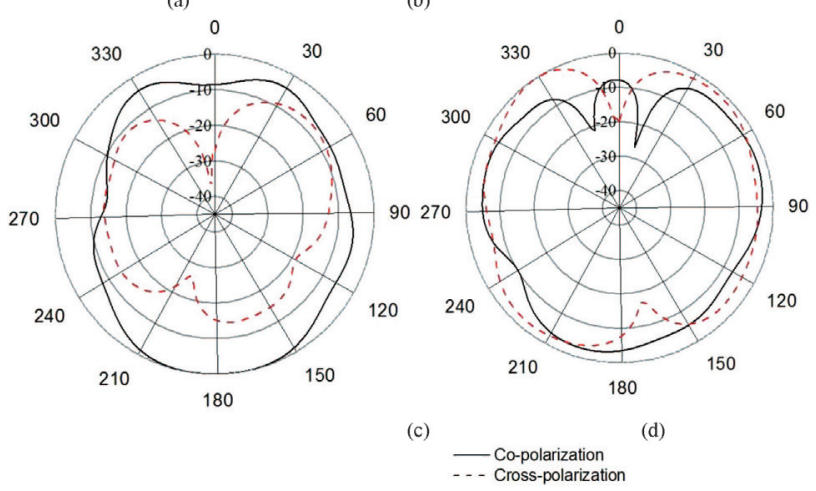

Figure 6: E-plane radiation pattern of the proposed antenna for frequency of: a) $1.8 \mathrm{GHz}$, b) $2.0 \mathrm{GHz}$, c) $3.6 \mathrm{GHz}$ and d) $5.2 \mathrm{GHz}$ Slika 6: Sledi sevanja v E-ravnini pri predlagani anteni, pri frekvencah: a) $1,8 \mathrm{GHz}$, b) $2,0 \mathrm{GHz}$, c) $3,6 \mathrm{GHz}$ in d) $5,2 \mathrm{GHz}$

phenomena, shown in Figure 7. The measured peak gain and radiation efficiency of the proposed antenna is presented in Figure 8. Figure 8 shows that the maximum radiation efficiency of $86 \%$ was obtained at $3.73 \mathrm{GHz}$. In addition, the maximum peak gain achieved at the lower band is $1.86 \mathrm{~dB}$, at the middle band it is $4.38 \mathrm{~dB}$ and at the upper band it is $4.31 \mathrm{~dB}$.
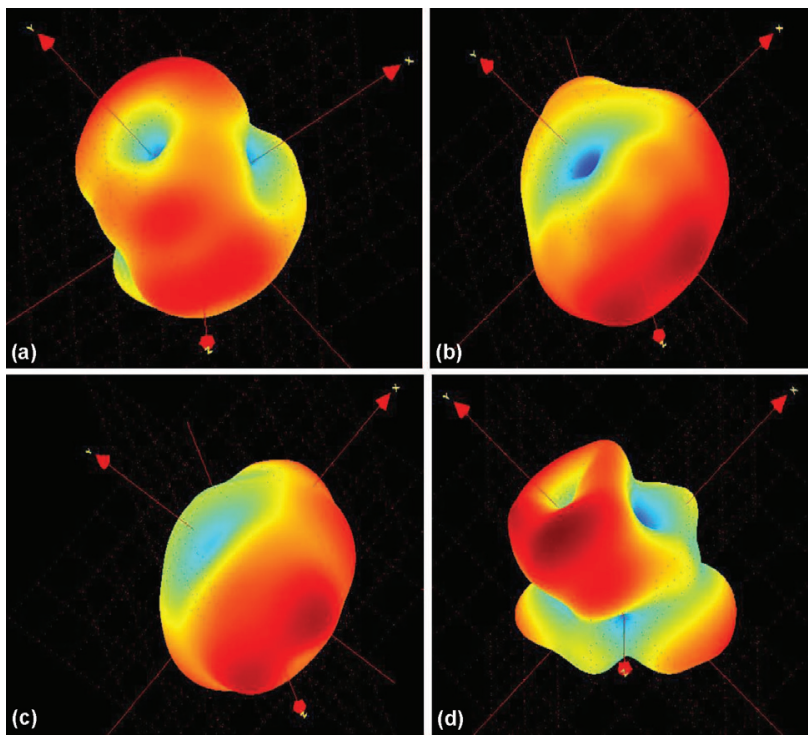

Figure 7: 3D radiation pattern of the proposed antenna for frequency of: a) $1.8 \mathrm{GHz}$, b) $2.0 \mathrm{GHz}$, c) $3.6 \mathrm{GHz}$ and d) $5.2 \mathrm{GHz}$

Slika 7: 3D-sledi sevanja predlagane antene pri frekvencah:

a) $1,8 \mathrm{GHz}$, b) $2,0 \mathrm{GHz}$ c) $3,6 \mathrm{GHz}$ in d) $5,2 \mathrm{GHz}$ 
T. ALAM et al.: BIO-PLASTIC COMPOSITE SUBSTRATE MATERIAL BASED MICROSTRIP-FED PRINTED ANTENNA ...

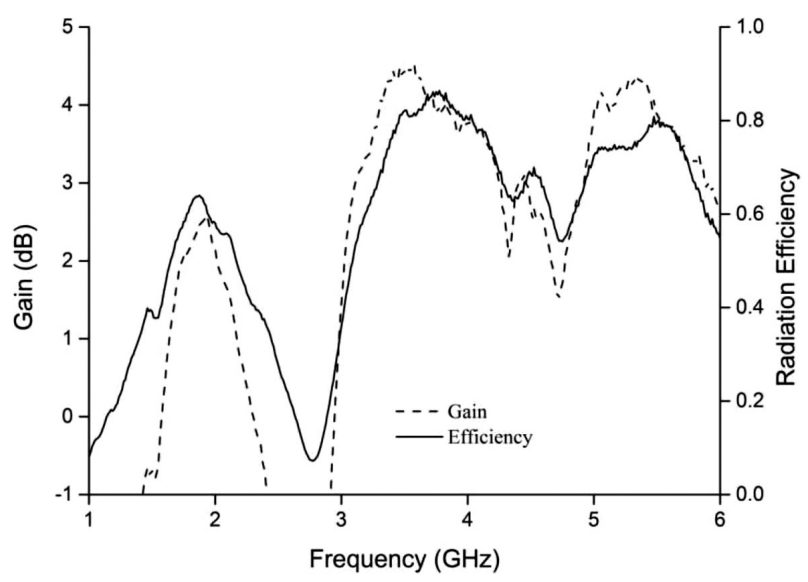

Figure 8: Radiation efficiency and gain of the proposed antenna Slika 8: Učinkovitost sevanja in izkoristek pri predlagani anteni

\section{EM ABSORPTION ANALYSIS}

The specific absorption rate is defined by the power absorbed per mass of biological tissues and has units of watts per kilogram (W/kg). Currently, two international organizations have developed guidelines for limiting the exposure of electromagnetic radiation on human health. The EM absorption limit specified in IEEE C95.1:2005 is $1.6 \mathrm{~W} / \mathrm{kg}$ in a $1 \mathrm{~g}$ averaging mass and $2 \mathrm{~W} / \mathrm{kg}$ in a $10 \mathrm{~g}$ averaging mass of tissue, which is similar to the limit stated in the International Commission on Non-Ionizing Radiation Protection (ICNIRP) guideline. ${ }^{11}$ To comply with the guidelines, the EM absorption values of the proposed antenna were analysed, and are listed in Table 2.

Table 2: SAR values of the proposed antenna

Tabela 2: SAR-vrednosti pri predlagani anteni

\begin{tabular}{|c|c|c|}
\hline Frequency $(\mathrm{GHz})$ & SAR $1 \mathrm{~g}(\mathrm{~W} / \mathrm{kg})$ & SAR $10 \mathrm{~g}(\mathrm{~W} / \mathrm{kg})$ \\
\hline 1.8 & 1.45 & 1.20 \\
\hline 2.0 & 1.38 & 1.06 \\
\hline
\end{tabular}

\section{CONCLUSION}

A new bio-plastic material based printed planar antenna is presented for GSM, UMTS, LTE band 40, WiMAX and WLAN wireless applications with accept- able specific absorption rates and antenna performance, like impedance bandwidth, antenna gain, radiation pattern and radiation efficiency. The experimental results validate the simulated results. Therefore, the overall performances of the proposed antenna make it suitable for a wireless mobile application.

\section{REFERENCES}

${ }^{1}$ T. Alam, M. R. I. Faruque, M. T. Islam, Printed Circular Patch Wideband Antenna for Wireless Communication, Informacije MIDEM, 44 (2014) 3, 212-217

${ }^{2}$ K. S. Sultan, H. H. Abdullah, E. A. Abdallah, E. A. Hashish, Low-SAR, Miniaturized Printed Antenna for Mobile, ISM, and WLAN Services, IEEE Antennas and Wireless Propagation Letters, 12 (2013), 1106-1109, doi:10.1109/LAWP.2013.2280955

${ }^{3}$ A. H. Kusuma, A.-F. Sheta, I. M. Elshafiey, Z. Siddiqui, M. A. Alkanhal, S. Aldosari, et al., A new low SAR antenna structure for wireless handset applications, Progress In Electromagnetics Research, 112 (2011), 23-40, doi:10.2528/PIER10101802

${ }^{4}$ C. Picher, J. Anguera, A. Andújar, C. Puente, S. Kahng, Analysis of the human head interaction in handset antennas with slotted ground planes, IEEE Antennas and Propagation Magazine, 54 (2012) 2, 36-56, doi:10.1109/MAP.2012.6230717

${ }^{5}$ A. Cabedo, J. Anguera, C. Picher, M. Ribo, C. Puente, Multiband Handset Antenna Combining a PIFA, Slots, and Ground Plane Modes, IEEE Transactions on Antennas and Propagation, 57 (2009) 9, 2526-2533, doi: 10.1109/TAP.2009.2027039

${ }^{6}$ T. Alam, M. R. I. Faruque, M. T. Islam, N. Misran, Composite-material printed antenna for a multi-standard wireless application, Mater. Tehnol., 49 (2015) 5, 745-749, doi:10.17222/mit.2014.132

${ }^{7}$ M. H. Ullah, M. Islam, Analysis of a ceramic filled bio-plastic composite sandwich structure, Applied Physics Letters, 103(2013), 223701, doi:10.1063/1.4833496

${ }^{8}$ D. Zhou, R. A. Abd-Alhameed, C. H. See, A. G. Alhaddad, P. S. Excell, Compact wideband balanced antenna for mobile handsets, IET Microwaves, Antennas \& Propagation, 4 (2010) 5, 600-608, doi:10.1049/iet-map.2009.0153

${ }^{9}$ Q. Rao, T. A. Denidni, New broadband dual-printed inverted L-shaped monopole antenna for tri-band wireless applications, Microwave and Optical technology letters, 49 (2007) 2, 278-280, doi:10.1002/mop.22107

${ }^{10}$ S.-B. Chen, Y.-C. Jiao, W. Wang, F.-S. Zhang, Modified T-shaped planar monopole antennas for multiband operation, Microwave Theory and Techniques, IEEE Transactions on, 54 (2006) 8, 3267-3270, doi:10.1109/TMTT.2006.877811

${ }^{11}$ IEEE Standard for Safety Levels With Respect to Human Exposure to Radio Frequency Electromagnetic Fields, $3 \mathrm{kHz}$ to $300 \mathrm{GHz}$, IEEE Std C95.1-2005, (2006), 0_1-238, doi:10.1109/IEEESTD. 2010.5433227 